\title{
PERSEPSI PELAKU USAHA TAMBAK TERHADAP PENANGGULANGAN BENCANA BANJIR DI PANTAI UTARA JAWA BARAT
}

\author{
"Lindawati dan Nendah Kurniasari \\ Balai Besar Penelitian Sosial Ekonomi Kelautan dan Perikanan \\ Gedung Balitbang KP I Lt. 4 \\ Jalan Pasir Putih Nomor 1 Ancol Timur, Jakarta Utara \\ Telp: (021) 64711583 Fax: 64700924 \\ *email: nda_1637@yahoo.com \\ Diterima 3 Juni 2014- Disetujui 2 Nopember 2014
}

\begin{abstract}
ABSTRAK
Tulisan ini bertujuan untuk mengetahui bagaimana persepsi pembudidaya tambak terhadap penanggulangan bencana banjir. Penelitian ini dilakukan di pantai Utara Jawa Barat, tepatnya di Kabupaten Subang dan Karawang. Data yang digunakan dalam penelitian ini menggunakan data primer dan sekunder. Data primer diperoleh melalui pendekatan survey dengan melakukan wawancara kepada pembudidaya tambak, sedangkan data sekunder diperoleh dari Dinas Kelautan dan Perikanan Kabupaten Subang dan Karawang. Pengambilan responden dilakukan secara purposive sampling dengan jumlah responden sebanyak 17 orang pembudidaya tambak. Hasil penelitian menunjukkan bahwa persepsi pembudidaya tambak terhadap ketepatan, kecepatan dan efektifitas penanggulangan bencana banjir masih rendah, baik pada saat situasi tanggap darurat maupun saat rehabilitasi usaha. Oleh karena itu, untuk mengantisipasi terjadinya banjir serta kerusakan dan kerugian yang lebih besar, pembudidaya tambak melakukan beberapa langkah yaitu membuat jaring atau waring yang dipasang di sepanjang kolam dan pintu air tambak untuk menghalangi ikan berpindah dari kolam ketika air tambak menjadi luber akibat banjir, membuat alat dari pipa paralon yang digunakan untuk membuka saluran air yang menghubungkan sungai dengan tambak ketika surut dan menutupnya ketika pasang sehingga air tambak tidak meluap, memperbaiki tambak menjadi lebih tinggi dan mengeruk lahan tambak lebih dalam dari sebelumnya, penanaman pohon mangrove yang berfungsi sebagai "rumah ikan" (fish apartement) pada saat terjadi banjir serta melakukan panen lebih awal untuk menghindari kerugian yang lebih besar.
\end{abstract}

Kata kunci: persepsi, pelaku usaha tambak, bencana banjir

\section{Abstract : Perception of Business Pond Flood Disaster in Coastal North West Java by: Lindawati dan Nendah Kurniasari}

This paper aimed to determine how the perception of several farms on the flood disaster management. The research was carried out in Subang and Karawang. Data used in this research using primary and secondary data. Primary data were collected through a survey approach by conducting interviews with actors on fish ponds, while secondary data obtained from the relevant agencies such as the Marine and Fisheries Agency in Subang and Karawang. Results showed that the perception of several fish farmers for the accuracy, effectiveness and speed of flood disaster management were still low, both during emergency situations or when rehabilitation efforts. Therefore, to anticipate flood damage and anticipate greater loss, fishpond farmers do some steps towards their ponds, namely : makes nets or waring mounted along the pond and pond water door to block the fish move from the pool when water overflow due to flooding, making pipe that used to open water channel that connects river to the pond when ebb and close it when tide so that water does not overflow pond, improving pond becomes higher and dredge ponds deeper than before, planting mangrove as a fish apartments when floods and early harvest prematurely to avoid more losses.

Keywords : perception, fish pond farmer, floods

\section{PENDAHULUAN}

Wilayah pesisir merupakan salah satu wilayah yang sangat rentan terhadap dampak perubahan iklim. Dampak tersebut meliputi kenaikan muka air laut, perubahan suhu permukaan air laut, perubahan pola cuaca dan iklim setempat dan semakin diperparah dengan adanya potensi bahaya alam lainnya seperti banjir, gempa, tsunami dan badai tropis. Kondisi tersebut memicu pada permasalah lainnya seperti meningkatnya erosi pantai, penggenangan lahan-lahan produktif dan fasilitas publik, intrusi air laur, meningkatnya intensitas dan frekuensi badai serta perubahan pola hujan (Hutabarat et. al., 2011).
Salah satu wilayah pesisir yang rawan terhadap dampak perubahan iklim (salah satunya akibat kenaikan muka air laut atau rob) adalah pesisir utara Pulau Jawa. Hal ini disebabkan kondisi pesisir Utara Pulau Jawa bertopografi landai sehingga banjir dapat dengan mudah sampai ke daratan. Wilayah pesisir utara Pulau Jawa identik dengan wilayah pesisir lainnya yang memiliki keragaman penggunaan lahan dan kepadatan penduduk yang cukup tinggi. Adanya bencana banjir tidak hanya mengakibatkan kerusakan fisik bangunan rumah dan sarana prasarana umum, tetapi juga terganggunya aktivitas sosial dan ekonomi masyarakat (Hardoyo et. al., 2011). 
Banjir merupakan suatu fenomena alam biasa, namun akan menjadi suatu yang sangat merugikan jika menganggu dan mengancam kehidupan manusia. Banjir yang terjadi pada awal tahun 2014 (tepatnya Bulan Januari-Maret 2014) telah menyebabkan banyak wilayah terendam. Banjir tersebut tidak hanya merendam pemukiman dan sarana prasarana umum, tetapi juga telah mengakibatkan kerusakan dan kerugian pada beberapa usaha, khususnya usaha perikanan budidaya tambak. Berdasarkan data yang dihimpun oleh Kementerian Kelautan dan Perikanan (KKP), kerugian akibat banjir pada sektor perikanan mencapai sekitar Rp. 587 miliar (Wilayah Banten, Jawa Barat, Jawa Tengah, Jawa Timur, Sumatera Utara dan Sulawesi Utara). Luas kawasan budidaya yang terendam banjir di empat provinsi di pantura Jawa mencapai 68.377 ha, yaitu (1) Provinsi Jawa Barat 49.843 ha; (2) Jawa Tengah 15.143 ha; (3) Banten 622 ha dan (4) Jawa Timur 2.377 ha (Ivansyah, 2014). Selain merusak tambak, banjir juga telah merusak infrastruktur yang menunjang sektor perikanan seperti irigasi dan kontruksi tambak. Banjir juga berdampak pada berkurangnya pendapatan masyarakat pembudidaya tambak.

Kejadian banjir yang merendam tambak warga pada awal tahun 2014 telah mendapatkan perhatian yang cukup besar dari pemerintah (dalam hal ini KKP) dalam bentuk Peraturan Pemerintah yaitu PERMEN-KP No.12/2014 tentang perlindungan nelayan, pembudidaya ikan dan petambak garam rakyat yang terkena bencana alam yang baru diundangkan pada 19 Maret 2014. Berdasarkan PERMEN-KP tersebut kementerian melalui direktorat jendral terkait dibawahnya secara ad hoc dapat mengalokasikan dana untuk memberikan bantuan kepada pembudidaya yang terkena dampak bencana. Akan tetapi, peraturan menteri terkait penanggulangan bencana yang ada belum dapat dijadikan landasan hukum yang kuat dan menyeluruh serta belum sesuai dengan perkembangan keadaan sehigga menghambat upaya penanggulangan bencana secara terencana, terkoordinasi dan terpadu. Oleh karena itu, dengan mengambil kasus di pantai Utara Jawa Barat, tepatnya di Kabupaten Subang dan Karawang, tulisan ini bertujuan untuk mengetahui persepsi pembudidaya tambak terhadap penanggulangan dampak banjir yang telah dilakukan oleh pemerintah, baik pemerintah daerah maupun pusat.

\section{METODOLOGI PENELITIAN}

\section{Waktu dan Lokasi Penelitian}

Penelitian ini dilaksanakan pada Bulan April-Mei 2014. Lokasi penelitian dilakukan di pantai Utara Jawa Barat, tepatnya di Kabupaten Subang dan Karawang. Pemilihan lokasi ini berdasarkan pada pertimbangan bahwa lokasi tersebut merupakan salah satu sentra usaha budidaya tambak dan terkena dampak banjir yang cukup parah pada awal tahun 2014, yaitu seluas 49.843 ha.

\section{Jenis dan Sumber Data}

Data yang diperoleh dalam penelitian ini berasal dari data primer dan data sekunder. Data primer diperoleh melalui survey dan observasi langsung dengan menggunakan panduan kuesioner kepada pembudidaya tambak terkait dengan persepsi mereka terhadap penanggulangan banjir, sedangkan data sekunder diperoleh dari Dinas Kelautan dan Perikanan Kabupaten Subang dan Karawang yang mencakup potensi dan perkembangan budidaya tambak di Kabupaten Subang dan Karawang, serta penelusuran melalui berbagai literatur yang terkait dengan topik penelitian.

Metode pengumpulan data dilakukan secara purposive sampling. Menurut Sugiyono (2008), purposive sampling merupakan pengambilan sampel secara sengaja sesuai dengan persyaratan sampel yang diperlukan. Jumlah responden yang digunakan dalam penelitian ini berjumlah 17 orang yang melakukan kegiatan usaha pada budidaya tambak.

\section{Metode Analisis}

Metode analisis data yang digunakan dalam penelitian ini menggunakan pendekatan deskriptif. Menurut Sugiyono (2008), analisis deskriptif merupakan metode penelitian dengan cara mengumpulkan datadata sesuai dengan yang sebenarnya, kemudian datadata tersebut disusun, diolah dan dianalisis untuk memberikan gambaran mengenai masalah yang ada. Analisis deskriptif digunakan untuk menggambarkan bagaimana persepsi pembudidaya tambak terkait dengan penanggulangan banjir yang dilakukan oleh pemerintah.

Analisis deskriptif dilakukan terhadap jawaban/persepsi pembudidaya tambak mengenai penanggulangan bencana banjir yang dianalisis berdasarkan tiga aspek yang mengacu pada kerangka analisis sebagaimana yang tertera pada Gambar 1, yaitu : (1) Aspek ketepatan yang mencakup sasaran penerima, jenis dan jumlah bantuan; (2) Aspek kecepatan waktu penyerahaan/penerimaan bantuan; dan (3) Aspek efektivitas mekanisme.

\section{HASIL DAN PEMBAHASAN}

\section{Perkembangan Produksi Perikanan Budidaya di Kabupaten Karawang}

Kabupaten Karawang memiliki potensi sumberdaya perikanan dan kelautan yang cukup besar, baik dari perikanan tangkap maupun perikanan budidaya. Pada perikanan budidaya, potensi yang dimiliki berasal dari tambak, kolam, mina padi dan KJA. Potensi yang dimiliki untuk tambak sekitar 18.273,30 ha (baru dimanfaatkan sekitar $15.567,40 \mathrm{ha}$ ), potensi kolam budidaya seluas $1.279,40$ ha (baru dimanfaatkan $1.188,19$ ha), potensi mina padi sekitar $10.580,80$ ha 


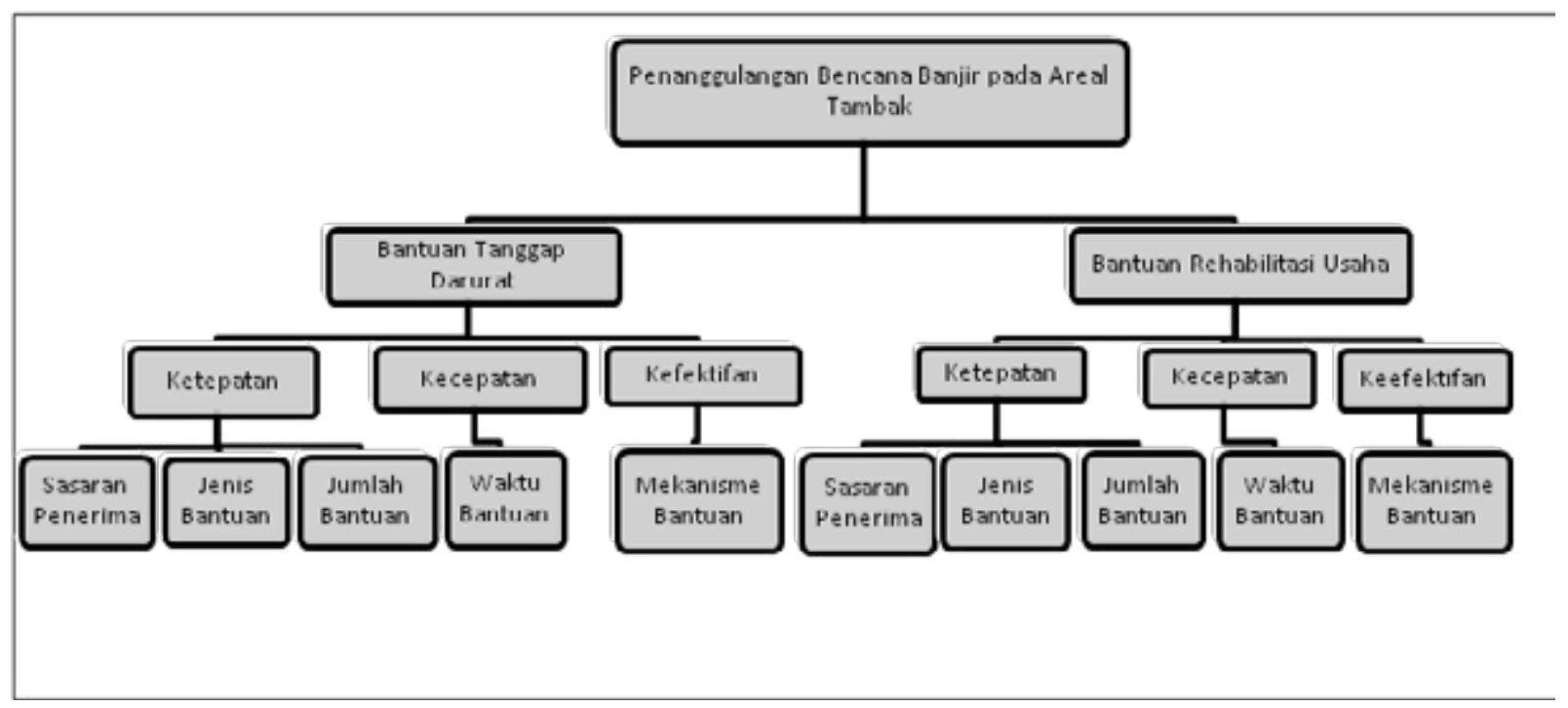

Gambar 1. Kerangka Analisis Persepsi Pembudidaya Tambak Terhadap Penanggulangan Bencana Banjir di Pantai Utara Jawa Barat

Tabel 1. Perkembangan Produksi Perikanan Budidaya Tahun 2009-2013 di Kabupaten Karawang.

\begin{tabular}{lrrrrr}
\hline \multirow{2}{*}{ Perikanan Budidaya } & \multicolumn{5}{c}{ Produksi (Ton) } \\
\cline { 2 - 6 } & \multicolumn{1}{c}{$\mathbf{2 0 0 9}$} & $\mathbf{2 0 1 0}$ & $\mathbf{2 0 1 1}$ & $\mathbf{2 0 1 2}$ & $\mathbf{2 0 1 3}$ \\
\hline Tambak & $35.005,49$ & $35.101,19$ & $35.267,54$ & $35.285,15$ & $36.648,48$ \\
Kolam & $2.221,28$ & $2.225,35$ & $2.492,99$ & $2.517,00$ & $2.605,89$ \\
Mina Padi & 671,47 & 611,92 & 409,8 & 364,17 & 360,87 \\
KJA & 164,98 & 165,17 & 225,74 & 206,26 & 237,44 \\
\hline \multicolumn{1}{c}{ Jumlah } & $\mathbf{3 8 . 0 6 3 , 2 2}$ & $\mathbf{3 8 . 1 0 3 , 6 3}$ & $\mathbf{3 8 . 3 9 6 , 0 7}$ & $\mathbf{3 8 . 3 7 2 , 5 8}$ & $\mathbf{3 9 . 8 5 2 , 6 8}$ \\
\hline
\end{tabular}

Sumber :Dinas Perikanan dan Kelautan Kabupaten Karawang (2014)

(baru dimanfaatkan 141,05 ha) dan potensi KJA sebanyak 168 unit (baru dimanfaatkan 79 unit). Adapun jumlah rumah tangga perikanan (RTP) untuk pembudiaya ikan adalah 7.871 RTP yang terdiri dari 4.229 RTP tambak, 3.033 RTP kolam, 514 RTP mina padi dan 95 RTP KJA.

Jika dilihat dari potensi sumberdaya yang dimiliki, potensi dari perikanan budidaya khususnya tambak masih berpotensi untuk terus dikembangkan mengingat masih sekitar $15 \%$ lagi yang belum dimanfaatkan. Hal ini terlihat dari perkembangan jumlah produksi ikan selama 5 (lima) tahun terakhir (2009-2013) yang mengalami kenaikan rata-rata sebesar $20 \%$, dengan nilai produksi yang paling besar berasal dari budidaya tambak seperti terlihat pada Tabel 2.

Tabel 2. Perkembangan Produksi Perikanan Budidaya Tahun 2009-2013 di Kabupaten Subang.

\begin{tabular}{lrrrrr}
\hline \multirow{2}{*}{ Perikanan Budidaya } & \multicolumn{5}{c}{ Produksi (Ton) } \\
\cline { 2 - 6 } & \multicolumn{1}{c}{$\mathbf{2 0 0 9}$} & $\mathbf{2 0 1 0}$ & $\mathbf{2 0 1 1}$ & \multicolumn{1}{c}{$\mathbf{2 0 1 2}$} & $\mathbf{2 0 1 3}$ \\
\hline Tambak & $12.885,72$ & $13.610,00$ & $14.563,04$ & $18.754,64$ & $28.541,31$ \\
Kolam Air Tenang & $6.256,97$ & $14.103,74$ & $14.187,98$ & $11.624,31$ & $9.276,00$ \\
Sawah & $1.168,87$ & 182,83 & 177,59 & 51,19 & 5,00 \\
Kolam Air Deras & $2.873,00$ & $4.708,19$ & $4.867,12$ & $5.138,26$ & $8.258,84$ \\
Budidaya Laut & 440,00 & 85,00 & 88,00 & 72,00 & 36,00 \\
Karamba & & & & 4,58 & 7,00 \\
\hline \multicolumn{1}{c}{ Jumlah } & $\mathbf{2 3 . 6 2 4 , 5 6}$ & $\mathbf{3 2 . 6 8 9 , 7 6}$ & $\mathbf{3 3 . 8 8 3 , 7 3}$ & $\mathbf{3 5 . 6 4 4 , 9 8}$ & $\mathbf{4 6 . 1 2 4 , 1 5}$ \\
\hline Sumber : Dinas Kelautan dan Perikanan Kabupaten Subang (2014) & & & &
\end{tabular}




\section{Perkembangan Produksi Perikanan Budidaya di Kabupaten Subang}

Pada Kabupaten Subang, potensi sumberdaya perikanan dan kelautan yang dimiliki berasal dari perikanan tangkap maupun perikanan budidaya. Dari sektor perikanan budidaya, potensi yang dimiliki cukup besar yaitu dari potensi tambak seluas 10.000 ha (baru dimanfaatkan seluas 7.941 ha), kolam seluas 900 ha (baru dimanfaatkan 107,5 ha), kolam air deras sebanyak 1600 unit (baru dimanfaatkan sebanyak 665 unit), dan mina padi seluas 13.000 ha (pemanfaatan seluas $28 \mathrm{ha}$ ). Jika dilihat dari potensi yang dimiliki tersebut, peluang usaha untuk budidaya ikan air payau di Kabupaten Subang masih sangat besar, hal ini juga didukung oleh panjang pantai yang dimiliki yang mencapai $68 \mathrm{~km}$ yang potensial untuk pengembangan usaha budidaya laut. Komoditas yang sangat cocok untuk dikembangkan adalah Rumput Laut (Euchema spp), Kakap (Lates carcarifer), Kerapu (Ephinephelus spp), Udang Windu (Paneus monodon), Udang Putih (Paneus marguensis), Bandeng (Channos channos) dan Kerang-kerangan serta jenis ikan lainnya (Anonim ${ }^{1}$. 2013).

Jika dilihat dari perkembangan produksi ikan selama 5 (lima) tahun terakhir (2009-2013) terjadi peningkatan rata-rata sebesar $20 \%$, dengan nilai produksi yang paling besar berasal dari budidaya tambak seperti terlihat pada Tabel 2. Untuk budidaya tambak, produksinya berasal dari udang windu, udang api-api, bandeng, dan jenis ikan lainnya.

\section{Persepsi Pembudidaya Tambak Terhadap Penanggulangan Bencana Banjir}

Menurut Suryantini et. al., (2010), bencana alam disuatu wilayah memiliki implikasi secara langsung terhadap masyarakat di wilayah tersebut. Partisipasi masyarakat untuk mengurangi dan menghindari resiko bencana penting dilakukan dengan cara meningkatkan kesadaran dan kapasitas masyarakat. Sedangkan Zein (2010) dalam Hardoyo et. al. (2011), menjelaskan bahwa masyarakat merupakan pihak yang memiliki pengalaman langsung dalam kejadian bencana sehingga pemahaman yang dimiliki menjadi modal bagi pengurangan resiko bencana. Dalam konteks manajemen bencana alam di wilayah pesisir, respon masyarakat terhadap bencana sangat penting untuk dipahami. Respon merupakan awal dari sebuah strategi adaptasi oleh masyarakat yang dihasilkan melalui pemahaman terhadap bencana alam yang terjadi. Pemahaman masyarakat berupa pengetahuan persepsi yang teraktualisasi dalam sikap dan atau tindakan dalam menghadapi bencana. Hasil dari sikap dan atau tindakan masyarakat dalam menghadapi bencana adalah strategi adaptasi yang berarti penyesuaian yang dilakukan akibat dari ancaman lingkungan.

Bencana banjir yang terjadi pada awal tahun 2014 telah menyebabkan banyak tambak yang terendam, sehingga menimbulkan kerusakan dan kerugian pada usaha budidaya tambak. Kerusakan yang ditimbulkan berupa kerusakan infrastruktur tambak seperti saluran irigasi dan kontruksi tambak. Selain itu, banjir juga menyebabkan kerugian akibat hilangnya biaya operasional dan hilangnya potensi keuntungan usaha. Terkait dengan bentuk bantuan yang digulirkan oleh pemerintah, pembudidaya menyatakan bahwa bantuan yang diberikan sering tidak tepat baik dalam hal jumlah, jenis dan waktunya, sehingga persepsi masyarakat terhadap bantuan yang dikeluarkan oleh pemerintah masih sangat rendah.

Berdasarkan hasil wawancara, persepsi pembudidaya terhadap penanggulangan bencana banjir terbagi menjadi dua, yaitu pada saat tanggap darurat dan rehabilitasi usaha. Tanggap darurat adalah serangkaian kegiatan yang dilakukan dengan segera pada saat kejadian bencana untuk menangani dampak buruk yang ditimbulkan, yang meliputi kegiatan penyelamatan dan evakuasi korban, harta benda, pemenuhan kebutuhan dasar, perlindungan, pengurusan pengungsi, penyelamatan, serta pemulihan prasarana dan sarana. Sedangkan rehabilitasi adalah perbaikan dan pemulihan sarana dan prasarana usaha masyarakat sampai tingkat yang memadai pada wilayah pasca bencana dengan sasaran utama normalisasi secara wajar usaha perikanan masyarakat di wilayah pasca bencana.

\section{(1) Bantuan Tanggap Darurat Penanggulangan Banjir}

Pada saat tanggap darurat, mekanisme penanggulangan banjir yang dirasakan oleh masyarakat pembudidaya tambak belum maksimal. Berdasarkan hasil wawancara, bantuan tanggap darurat sangat minim baik dalam jumlah maupun bentuknya. Bahkan sebagian masyarakat merasa mereka tidak mendapatkan bantuan dari pemerintah tapi dari perorangan terutama dari para calon anggota legislatif yang sedang berkampanye (karena pada saat terjadinya banjir sedang musim kampanye). Harapan masyarakat yang terkena banjir adalah bantuan berupa makanan pokok yaitu dalam bentuk beras, bukan mie instan. Selain itu, sebagian responden merasa bahwa bantuan tersebut waktunya terlambat. Ketika banjir mereka tidak bisa bepergian keluar rumah untuk membeli bahan makanan, sedangkan bantuan bahan makanan ada setelah dua sampai tiga hari dari bencana banjir. Pada Tabel 3 dapat dilihat persepsi pembudidaya tambak terhadap penyelenggaraan bantuan tanggap darurat.

\section{(2) Bantuan Rehabilitasi Usaha Akibat Banjir}

Terkait dengan bantuan rehabilitasi usaha, pada saat penelitian ini dilakukan belum ada satupun petambak yang menerima bantuan. Sehingga persepsi masyarakat terhadap penanganan rehabilitasi usaha sebagai dampak bencana banjir dinilai sangat buruk. Tabel 4 menunjukkan persepsi masyarakat terhadap bantuan rehabilitasi usaha akibat bencana banjir. 
Tabel 3. Persepsi Pembudidaya Tambak Terhadap Penyelenggaraan Bantuan Tanggap Darurat di Kabupaten Subang dan Karawang.

\begin{tabular}{|c|c|c|}
\hline \multirow{2}{*}{ Variabel } & \multicolumn{2}{|c|}{ Persepsi Petambak } \\
\hline & Kondisi sekarang & Harapan \\
\hline Ketepatan terhadap sasaran & $\begin{array}{l}\text { Tepat sasaran, namun tidak semua } \\
\text { menerima }\end{array}$ & $\begin{array}{l}\text { Tepat sasaran, semua yang terkena musibah } \\
\text { mendapatkan bantuan secara adil. }\end{array}$ \\
\hline Jenis bantuan & $\begin{array}{l}\text { Kurang tepat, sebagian hanya menerima } \\
\text { mie instan bukan beras }\end{array}$ & Sembako \\
\hline Jumlah bantuan & Sedikit & $\begin{array}{l}\text { Cukup dan memadai sampai bisa beraktivitas } \\
\text { mencari nafkah secara normal }\end{array}$ \\
\hline Waktu bantuan & terlambat & Pada saat bencana terjadi \\
\hline Mekanisme bantuan & Melaui desa, perlu pengawasan. & $\begin{array}{l}\text { - Melaui dinas KP karena daftar kelompok } \\
\text { petambak ada di dinas. } \\
\text { - Jika melalui Desa harus melalui pengawasan } \\
\text { dari DKP karena kadang-kadang petugas desa } \\
\text { memberikan bantuan berdasarkan kedekatan } \\
\text { personal. } \\
\text { - Melalui TPHT/koperasi setempat, karena } \\
\text { TPHT/koperasi mengetahui mana yang } \\
\text { petambak dan mana yang bukan petambak. }\end{array}$ \\
\hline
\end{tabular}

Sumber: Data Primer Diolah, 2014

Tabel 4. Persepsi Petambak Terhadap Bantuan Rehabilitasi Usaha Akibat Bencana Banjir.

\begin{tabular}{|c|c|c|}
\hline \multirow{2}{*}{$\begin{array}{l}\text { Variabel ketepatan } \\
\text { bantuan }\end{array}$} & \multicolumn{2}{|r|}{ Persepsi } \\
\hline & Kondisi sekarang & Harapan \\
\hline $\begin{array}{l}\text { Ketepatan terhadap } \\
\text { sasaran }\end{array}$ & Belum terlihat & Tepat sasaran sesuai dengan jumlah kerugian \\
\hline Jenis bantuan & Belum ada, baru pendataan & $\begin{array}{l}\text { - Fisik, berupa perbaikan infrastruktur } \\
\text { - Modal perbaikan usaha/produksi }\end{array}$ \\
\hline Jumlah bantuan & Belum ada, baru pendataan & $\begin{array}{l}\text { - Infrastruktur harus dibangun dengan kuat sehingga tidak setiap } \\
\text { banjir diperbaiki, } \\
\text { - Modal usaha sesuai dengan kerugian yang diderita }\end{array}$ \\
\hline Waktu bantuan & Sangat terlambat & Tidak terlambat \\
\hline Mekanisme & Tidak tahu & $\begin{array}{l}\text { Untuk perbaikan infrastruktur, bisa melalui apa saja yang penting } \\
\text { kuat, sedangkan } \\
\text { Untuk bantuan modal usaha sebaiknya melalui: } \\
\text { - Dinas KP karena daftar kelompok petambak ada di dinas. } \\
\text { - Jika melalui Desa harus melalui pengawasan dari DKP karena } \\
\text { kadang-kadang petugas desa memberikan bantuan berdasarkan } \\
\text { kedekatan personal. } \\
\text { - Melalui TPHT/koperasi setempat, karena TPHT/koperasi tau mana } \\
\text { petambak dan mana yang bukan }\end{array}$ \\
\hline
\end{tabular}

Sumber: Data Primer Diolah, 2014

Tabel 4 menunjukkan bahwa para pembudidaya tambak merasa bahwa mekanisme bantuan rehabilitasi usaha yang selama ini dilaksanakan belum efektif dapat membantu mereka untuk memulihkan usahanya. Sehingga bagi para pembudidaya tambak yang tidak mempunyai modal untuk memperbaiki kerusakan pada tambaknya, maka usahanya belum bisa beroperasi. Selain itu, pembudidaya juga merasa bahwa perbaikan infrastruktur yang rusak akibat banjir belum maksimal. Sebagai contoh, banjir yang terjadi di Karawang (Cilamaya Wetan) dipicu oleh rusaknya tanggul kalen bawah yaitu salah satu tanggul irigasi yang merupakan sumber pengairan tambak. Padahal, menurut para pembudidaya tambak, tanggul tersebut sudah sering diperbaiki namun karena kualitas perbaikan kurang baik sehingga setiap terjadi banjir masih sering jebol.

Oleh karena itu, dalam rangka mengurangi kerugian dan kerusakan yang diakibatkan oleh bencana banjir serta terlambatnya bantuan yang dilakukan oleh pemerintah, maka strategi yang dilakukan oleh pembudidaya terhadap tambaknya untuk mengantisipasi terjadinya banjir adalah dengan membuat jaring atau waring yang dipasang di sepanjang kolam dan pintu air tambak untuk menghalangi ikan berpindah dari kolam ketika air tambak menjadi luber akibat banjir, membuat alat dari pipa paralon yang digunakan untuk membuka saluran air yang menghubungkan sungai dengan tambak ketika surut dan menutupnya ketika pasang sehingga 
air tambak tidak meluap, memperbaiki tambak menjadi lebih tinggi dan mengeruk lahan tambak lebih dalam dari sebelumnya, penanaman pohon mangrove yang berfungsi sebagai " rumah ikan" (fish apartement) pada saat terjadi banjir serta melakukan panen lebih awal sebelum waktunya untuk menghindari kerugian yang lebih banyak.

\section{KESIMPULAN DAN IMPLIKASI KEBIJAKAN}

\section{Kesimpulan}

Banjir yang melanda pada awal tahun 2014 telah menyebabkan banyak wilayah terendam, termasuk juga usaha budidaya (ikan dan udang) dalam tambak. Banjir tersebut telah menyebabkan kerusakan dan kerugian pada usaha budidaya tambak. Meskipun pemerintah dalam hal ini Kementerian Kelautan dan Perikanan (KKP) telah membentuk peraturan pemerintah terkait dengan perlindungan terhadap pembudidaya perikanan, akan tetapi hasilnya belum dapat dirasakan oleh pembudidaya perikanan khusunya pembudidaya tambak. Terkait dengan penanggulangan bencana banjir yang telah dilakukan oleh pemerintah baik pada saat tanggap darurat maupun rehabilitasi usaha, persepsi pembudidaya tambak terhadap ketepatan, kecepatan dan efektifitas penanggulangan masih rendah, hal ini dikarenakan bantuan yang diberikan pada saat terjadi bencana banjir belum dirasakan oleh pembudidaya tambak.

\section{Implikasi Kebijakan}

Terkait dengan penanggulangan bencana banjir pemerintah diharapkan dapat memberikan bantuan dalam jumlah, jenis dan waktu yang tepat, sehingga kegiatan usaha budidaya tambak dapat segera beroperasi setelah terjadinya banjir. Selain itu, pemerintah baik pusat maupun daerah sebagai pelaksana penanggulangan bencana mempunyai pedoman dalam bentuk Standart Operasional Prosedure (SOP) yang dapat dijadikan acuan, baik dalam rangka valuasi dampak kerugian sebagai akibat bencana alam maupun tindak lanjut yang diperlukan secara cepat. Di samping itu, perlu adanya payung hukum bersifat nasional dalam bentuk undangundang sehingga memungkinkan bergulirnya dana penanggulangan bencana alam secara 'on top'.

\section{DAFTAR PUSTAKA}

Dinas Perikanan dan Kelautan Kabupaten Karawang. 2014. Laporan Tahunan. Kabupaten Karawang.

Dinas Perikanan dan Kelautan Kabupaten Subang. 2014. Laporan Tahunan. Kabupaten Subang.
Hardoyo, S. R., M.A. Marfai, N.M. Ni'mah, R.Y. Mukti, Q. Zahro dan A. Halim. 2011. Strategi Adaptasi Masyarakat dalam Menghadapi Bencana Banjir Pasang Air Laut di Kota Pekalongan. Magister Perencanaan dan Pengelolaan Pesisir dan Daerah Aliran Sungai (MPPDAS). Program S-2 Geografi, Fakultas Geografi Universitas Gadjah Mada. Yogyakarta. Cetakan Pertama. November 2011. Percetakan Pohon Cahaya.

Hutabarat, J., S. Diposaptono dan D.N. Sugianto. 2011. Strategi Adaptasi dan Mitigasi Bencana Pesisir Akibat Perubahan Iklim Terhadap Pesisir dan Pulau-Pulau Kecil. Disampaikan Dalam Rangka Simposium Nasional Perubahan Iklim 2011, Kerjasama Kementerian Lingkungan Hidup (KLH) dan Universitas Diponegoro (UNDIP). 26 Juli 2011.

Ivansyah. 2014. Kerugian Banjir Sektor Perikanan Rp. 500 Miliar. Tempo.co, 24 Februari 2014.http://www. tempo.co/read/news/2014/02/24/058557205/ Kerugian-Banjir-Sektor-Perikanan-Rp-500Miliar-. Diunduh Tanggal 5 November 2014.

Kurniasari, N., S. Koehendrajana, A. Ramadhan, F. N. Priyatna, A. Ramadhan dan Lindawati. 2014. Laporan Kajian Khusus :Evaluasi Dampak Banjir Terhadap Kerberlanjutan Usaha Budidaya Udang dan Ikan di Tambak. Balai Besar Penelitian Sosial Ekonomi Kelautan dan Perikanan. Badan Penelitian dan Pengembangan Kelautan dan Perikanan. Kementerian Kelautan dan Perikanan. Tidak Dipublikasikan.

Peraturan Menteri Kelautan dan Perikanan Republik Indonesia Nomor 12 Tahun 2014 tentang Perlindungan Nelayan, Pembudidaya Ikan dan Petambak Garam Rakyat yang Terkena Bencana Alam.

Sugiyono. 2008. Metode Penelitian Kuantatif Kualitatif dan R\&D. Bandung Alfabeta.

Suryanti, E.D., Rahayu, L., dan Retnowati, A. (2010). "Motivasi dan Partisipasi Masyarakat dalam Upaya Pengurangan Multirisiko Bencana di Kawasan Kepesisiran Parangtritis" dalam Penaksiran Multirisiko Bencana di Wilayah Kepesisiran Parangtritis, Yogyakarta, PSBA UGM.

Zein, M. (2010). “A Community Based Approach to Flood Hazard and Vulnerability ssessment in Flood Prone Area: A Case Study in Kelurahan Sewu, Surakarta City, Indonesia", Thesis, ITC, The Netherland. 